\title{
ЯЗЫКОЗНАНИЕ
}

\author{
ГАРМОНИЯ КАК ПРИНЦИП ОБРАЗОВАНИЯ ДЕФИСНЫХ \\ СУБСТАНТИВНО-СУБСТАНТИВНЫХ КОНСТРУКЦИЙ \\ (НА ПРИМЕРЕ ЕДИНИЦ ЛИЧНОЙ СЕМАНТИКИ) \\ HARMONY AS A PRINCIPLE IN CREATING HYPHENATED \\ COMPOUND WORDS \\ (BASED ON THE EXAMPLES OF NAMES FOR PEOPLE)
}

\section{PAULINA BORTNOWSKA}

\begin{abstract}
Using the structure of hyphenated compound words has become a productive way of creating new nominations in contemporary Russian. The aim of this article is to show that harmony as an orderly combination of elements in a whole is the main concept that underpins multiple psycholinguistic processes, resulting in the occurrence of hyphenated compound words in Russian speakers' language.

Paulina Bortnowska, Uniwersytet im. Adama Mickiewicza w Poznaniu, Poznań - Polska, pkbortnowska@gmail.com

Одним из продуктивных способов номинации в современном русском языке является образование дефисных субстантивно-субстантивных конструкций (ДССК) типа юбка-хвост, смартфон-раскладушка, фильм-ограбление, сумка-холодильник. Среди них особое место занимают единицы личной семантики, такие как хакер-фрикер, женщина-вамп, человек-матрешка и т. д., представляющие собой удобное средство разносторонней характеристики человека как центральной фигуры языка.

ДССК - это особые лексические объекты, в которых удобство формы и семантическая прозрачность гармонируют с семантической емкостью, а иногда даже и с необыкновенной оригинальностью смыслового содержания. Будучи результатами комбинаторики уже имеющихся в лексиконе единиц, структуры данного типа успешно отвечают условиям современной коммуникации, а также отражают тенденцию к регулярности в развитии языка. К тому же, выражая понятия более эксплицитно, чем однословные лексемы, они фиксируют в себе результаты усложенных процессов восприятия, понимания и концептуализации фрагментов окружающей действительности в сознании говорящих.
\end{abstract}


Стремясь постичь основные психолингвистические механизмы, обеспечивающие носителям русского языка возможность создавать, использовать и правильно интерпретировать ДССК в речевых реализациях, можно прийти к выводу, что словом-ключом, определяющим всю совокупность этих процессов, является гармония, понимаемая как 'соразмерность частей, слияние различных компонентов объекта в единое органическое целое' 1 . Причем, по нашим наблюдениям, гармония, сопровождающая возникновение ДССК в потоке речи, проявляется как на семантико-смысловом, так и на структурно-формальном уровнях.

Результатом семантико-смысловой гармонии ДССК является, в первую очередь, их семантическая цельность. Ученые неоднократно подчеркивали, что, будучи сложными номинатами, ДССК направляются на именуемый предмет комплексно, „как нечто концептуально целое” 2 .

Следует при этом отметить, что возникающие между компонентами ДССК семантико-смысловые связи всегда опираются на реальные смысловые соотношения между называемыми с их помощью объектами окружающей действительности и в большинстве случаев имеют свое отражение в форме системных и общеязыковых синтагматических, эпидигматических и парадигматических связей слов. Интенсивность семантико-смысловых связей, возникающих между компонентами семантически цельных ДССК, мы называем семантической регулярностью. По уровню семантической регулярности ДССК можно разделить на четыре типа.

К первому из них причисляются конструкции, компоненты которых связываются полностью комплектующей связью в рамках оппозиции тождества или привативной оппозиции гиперо-гипонимического характера, напр. невежда-дилетант, враг-супостат, путь-дорога, правда-истина, с одной стороны, и женщина-вамп, ребенок-грудничок, мужчина-метросексуал - с другой. Уровень семантической регулярности ДССК данного типа можно определить как абсолютный.

Второй тип представляют ДССК, отношения между компонентами которых опираются либо на их принадлежность к одной лексико-семантической подгруппе 3 (напр. любовница-жена, юноша-мужчина, активист-общественник, актриса-певициа), либо на привативную оппозицию неполностью комплектующего характера (напр. профессор-фрилолог: филолог - 'специалист по филологии'; ТСШ, жандарм-гаишник: гаишник - 'работник Государственной автомобильной инспекции'; ТСШ, друг-

${ }^{1}$ Большой энииклопедический словарь, ред. В.Н. Ярцева, Москва 1998.

2 Е.Ю. В и д а н о в, Аналитизм в именном словообразовании современного русского языка. Автореф. дисс. ...канд. филол. наук, Омск 2011, с. 11.

${ }^{3}$ Согласно классификации, представленной в Русском семантическом словаре Н.Ю. Шведовой. 
-одноклассник: одноклассник - 'ученик того же класса, в котором кто-н. учится, учился'; ТСШ). В случае таких структур можно, на наш взгляд, говорить о высоком уровне семантической регулярности.

К третьему типу относятся конструкции, связь между компонентами которых осуществляется в пределах одной тематической группы (напр. сын-наследник, бандит-предприниматель, еретик-митрополит) или разных подгрупп одной лексико-семантической группы (напр. паренъ-задохиик, эксиентрик-пустослов, друг-иностранеи). В силу большей отдаленности значений слов-компонентов такие ДССК называем условно регулярными.

Последний, четвертый, тип представляют конструкции, отношения между компонентами которых не имеют своих источников в системных языковых связях слов, а опираются на реальные соотношения между элементами окружающей человека действительности. Репрезентанты этого типа - метафорические ДССК, в которых один из компонентов способствует активизации переносного значения другого компонента, напр. человек-телевизор, женщиина-птичка, мужчина-огонь.

Особая гармония, связывающая друг с другом компоненты ДССК в цельную номинативную единицу, может действовать также вне пределов самой конструкции. Как замечает М.А. Дрога, семантико-смысловая гармония ДССК неоднократно проявляется уже на уровне контекста. Высказывания, в которых употребляются структуры данного типа, зачастую содержат определенные мотиваторы, т. наз. слова-стимулы, активизирующие процесс их (т. е. ДССК) порождения4. В связи с этим можно предполагать, что контекст играет двойную роль: он не только способствует правильному пониманию значения ДССК, но также предопределяет ее появление в тексте 5 . $\mathrm{O}$ „порождающей энергии контекста" пишет и Н.Д. Голев, обращая внимание на факт, что выбор, создание или воссоздание номинативной единицы обусловливается не только результатами интеллектуальных усилий говорящего, но также, в существенной степени, семантической материей контекста, которая „подготавливает” говорящего к применению определенного наименованияб.

Гармонию, возникающую между ДССК и сопровождающим ее контекстом, т. е. насыщенность текста определенными словами-стимула-

${ }^{4}$ М.А. Д р о га, Составные наименования в русском языке (ономасиологический и функцииональный аспекты). Автореф. дисс. ...канд. филол. наук, Белгород 2010, с. 16.

5 Там же.

${ }^{6}$ Н.Д. Г о л е в, Эпидигматика и деривационные процессы в речи. Детерминационный апсект, [в:] Проблемы деривации в системе языка и речевой деятельности (синхронное словообразование и номинация): межвузовский сборник научных трудов, Москва 1995, c. $19-28$. 
ми, М.А. Дрога называет ономасиологической плотностью текста7. В качестве слов-стимулов могут выступать:

- слова однокоренные с компонентами ДССК,

- слова, находящиеся с этими компонентами в синонимических или антонимических отношениях,

- слова, относящиеся к той же, что и компоненты ДССК, тематической группе,

- различного рода ассоциаты.

Сомнений не должно вызывать то, что ономасиологическая плотность текста играет существенную роль прежде всего в случае конструкций с усложненной семантической структурой. Именно в таких ДССК оригинальность и неожиданность сочетания конкретных слов-компонентов, как кажется, выходит на первый план:

Девушка-бестселер (подзаголовок). Но особенно хороша была барышня $\mathbf{k} к и$ тически укороченной одежде, которая своим видом превращуала книжную лавку В подиум. Полтора килограмма дерзкого макияжа, ноги "от зубов" и потрясающая томность напоминали о том, что всем хорошим в своей жизни человек обязан книгам. Девушка медленно шествовала меж стеллажей и тщательно наманикюренными коготками изредка трогала корешки собрания сочинений Анны Ахматовой. [...] Далее выяснилось, что работа у девушки тяжелая, постоянно В третью смену; ветер на Тверской делает ее (работу) совсем уж невыносимой. А в книжном магазине тепло, светло и люди интеллигентные: не заламывают руки и не волокут 8 патрульную машину. Из Всех литературных жанров тургеневская красавиияа больше всего изенит поэзию и труды по бухгалтерии. Первая смягчает грубость профессии, а пособия по ведению гроссбухов пользуются большой популярностью среди менеджеров крупных фирм (1).

В приведенном контексте ДССК дебушка-бестселер выполняет функцию заголовка, т. е. в ней, по намерению автора, содержится общий смысл, основная мысль данной части текста. Присутствие компонента бестселлер, на наш взгляд, мотивируется как с помощью явно выраженных в контексте слов-стимулов, связанных общей темой „книга” (собрание сочинений, книжный магазин, литературные жанры, поэзия, труды по бухгалтерии), так и неявными, скрытыми семами, которые читатель должен понимать интуитивно, опираясь на свой жизненный опыт и фоновые знания. На эти неявные семы, которые должны навести читателя на слово проститутка, замененное автором компонентом бестселлер, намекают такие элементы текста, как описание внешности девушки-бестселера (критически укороченная одежда, полтора килограмма дерзкого макияжа) или информация о характере работы девушки ([работа] постоянно в третью смену, ветер на ТВерской делает ее [работу]

7 М.А. Д р о г а, указ. соч. 
совсем уж невыносимой, поэзия [...] смягчает грубость профессии). Однако смысловая связь между словами бестселер и проститутка осуществляется также на уровне их лексических значений, общим элеменентом которых является сема „торговля": 'бестселер - популярная, быстрее других раскупаемая книга' (ТСШ); 'проститутка - женщина, занимающаяся проституциееи' (ТСШ), 'проституция - продажа женщинами своего тела с целью добыть средства к существованию, а также с целью личного обогащения' (ТСШ).

Кроме семантико-смыслового, немаловажную роль играет также структурно-формальный аспект гармонии ДССК. К часто упоминаемым его проявлениям можно отнести такие особенности анализируемых структур, как корреляция падежных форм (ср. учитель-словесник, учителя-словесника, об учителе-словеснике и т. д.) или графическая слитность, выражающаяся в дефисном написании. Гармония ДССК проявляется неоднократно и на фонетическом уровне. Под понятием фонетической гармонии мы подразумеваем целесообразное употребление в качестве компонентов ДССК лексем, похожих по звуковой оболочке. Это могут быть как слова, между которыми возникает рифма, опирающаяся на общность суффиксов, напр. толстяк-здоровяк, толстячок-круглячок, бабушка-старушка, алкаш-папаша, лжеи-подлеи, принцесса-роботесса, так и слова, фонетическое сходство между которыми осуществляется в пределах корней и аффиксов, напр. гад-бюрократ, гад-демократ, жених-лопух, или же целых слов, напр. дура-кура. Фонетическая гармония, которая возникает между компонентами таких ДССК, усиливает, как кажется, их лексическую цельность, так как связь между этими компонентами осуществляется на трех уровнях: графическом, семантико-функциональном и, именно, фонетическом.

Стоит обратить внимание на то, что внутренняя фонетическая гармония неоднократно отражается в какой-то степени и во всем высказывании, в котором появляется ДССК. Самый яркий пример этого явления, которое можно соотнести с обсуждаемой нами раньше ономасиологической плотностью текста, - короткие рифмованные поговорки. Приведем одну из них, которая вошла в русский язык благодаря короткометражному детскому мультфильму Мешок яблок:

Четыре сыночка и лапочка-дочка (2).

Также в современной русской прессе можно обнаружить примеры рифмованных предложений, центральным элементом которых являются ДССК. Ниже приводим два контекста:

После шестой рюмки: Две подружки-хохотушки перепутали частушки... (3);

Когда я поинтересовалась, мол, на какие шиши, подружки дружно рассмеялись: „У старушки-побирушки миллион нашли в подушке” (4). 
Следует обратить внимание на то, что рифмизация высказывания является одной из характерных черт народного творчества. Приведенные выше примеры наглядно показывают, что этот прием используется и в современных текстовых реализациях. В данном контексте нам хотелось бы воспользоваться еще фрагментом неозаглавленного стихотворения современного русского поэта Т. Кибирова, в котором прием фонетической гармонии между ДССК и контекстом используется ради его фольклорной стилизации:

$$
\begin{aligned}
& \text { Послушай, кликуша, найди себе мужа! } \\
& \text { Не надо орать нам в прижатые уши! } \\
& \text { Не надо спасать наши грешные души! } \\
& \text { Иди-ка ты с Богом, мамаша-кликуша! (5). }
\end{aligned}
$$

В этом стихотворении форму ДССК получает наименование кликуши - женщины, страдающей кликушеством, т. е. проявлением 'истерии [...], выражающемся в судорожных припадках, выкриках, причитаниях, взвизгиваниях, бурной жестикуляции' (ТСЕ). Появление такого персонажа характерно для простонародных представлений о мире. В напоминающем заклинание фрагменте стихотворения фонетическая гармония достигается путем повторения фонемы $\check{s}$ как в структуре ДССК мамаша-кликуша, так и в словах послушай, уши, наши, грешные, души, а также соотносящейся с ней звонкой фонемы ž: мужа, прижатые. На наш взгляд, приведенный пример показывает авторские попытки использования приема фонетической гармонии для усиления фатической энергии высказывания.

Интересный пример фонетической гармонии мы нашли и в следующем контексте:

Он же придумывал ей все новые и новые смешные прозвища:

„Шептун-Топтун" (за то, что шуршала длинными юбками), „милый рыжичек”, „милая моя маточка", „Рыжий дьявол" и т. п. (6).

Здесь фонетическая гармония между ДССК и контекстом выражается в двух планах. Во-первых, она проявляется в структуре предложения, в котором, кроме ДССК шептун-топтун, в начале которого находится шипящий звук š, накопились и другие слова с шипящими фонемами š и г̌: же, смешные, прозвища, что, шуршала, рыжичек, маточка, рыжий. Во-вторых, в более широком смысле можно сделать вывод о некотором фонетическом предпочтении автора названных в предложении прозвищ к шипящим звукам, так как именно эти звуки являются общим элементом его обращений к любимой женщине: Шептун-Топтун, милый рыжичек, милая моя маточка, Рыжий дьявол.

Очень интересным примером накопления однородных фонем в высказывании мы считаем следующее предложение: 
Болтали, будто поселил туда хозяин-купеи, свою мюбовнииу-танцовщииу и, пуще того, за неверность приказал замуровать изменщииу в стенку вместе со всеми драгоценностами (7).

Здесь, кроме гармонии между суффиксами компонентов ДССК ююбовница-танцовщица, наблюдается насыщенность целого высказывания фонемами $c, s, s^{\prime}, t^{\prime}, z$, которые появляются почти в каждом слове: поселить, хозяин, купеи, за, неверность, приказать, замуровать, изменщица, стенка, вместе, все, драгоценности.

Подводя итоги, мы еще раз напомним, что, по нашим наблюдениям, гармония ДССК выражается на двух уровнях: семантико-смысловом и структурно-формальном. Причем на каждом из этих уровней она проявляется в двух планах: внутренней гармонии, возникающей между компонентами ДССК, и внешней гармонии, возникающей между ДССК и контекстом, в котором данная конструкция появляется. На наш взгляд, это наблюдение является еще одним доказательством того, что ключевой для функционирования ДССК в русском языке является их цельность, опирающаяся на особое единство двух, доныне самостоятельных, полнозначных слов. К тому же, учитывая огромную роль человеческого фактора в языке, нельзя не обратить внимания на уникальную интуитивность схем подбора слов-компонентов ДССК, а также сопровождающих их контекстуальных мотиваторов (принимающих форму слов-стимулов и/или слов с похожей звуковой оболочкой). Именно интуитивность процесса образования цельных по своей природе ДССК показывает, насколько системные связи языковых объектов представляют собой интегральную часть языкового сознания носителей языка. Поэтому, на наш взгляд, ДССК стоит рассматривать как особые единицы языка и речи, которые могут быть ключом к изучению основных механизмов номинации в современном русском языке и привести к более глубокому пониманию процессов формирования языковой личности носителей русского языка.

\section{Bibliografia}

Большой энииклопедический словарь, ред. В.Н. Ярцева, Москва 1998.

В и д а н о в Е.Ю., Аналитизм в именном словообразовании современного русского языка. Автореф. дисс. ...канд. филол. наук, Омск 2011.

Г о л е в Н.Д., Эпидигматика и деривационные процессы $b$ речи. Детерминационный апсект, [в:] Проблемы деривации в системе языка и речевой деятельности (синхронное словообразование и номинация): межвузовский сборник научных трудов, Москва 1995.

Д р о г а М.А., Составные наименования в русском языке (ономасиологический и функциональный аспекты). Автореф. дисс. ...канд. филол. наук, Белгород 2010.

Русский семантический словарь: толковый словарь, систематизированный по классам слов и значений, ред. Н.Ю. Шведова, т. 1, Москва 1998. 


\section{Источники материала:}

Б л а г о д а р о в К., Сколько книжек ни бери, все равно еще раз бежать, „Комсомольская правда" 07.10.2002.

Д е р к а ч О., Б ы к о в В., Московская азбука, „Комсомольская правда” 07.05.2001.

Е м ель я н о в С., К а л е ч иц А., П о н о м а р е в С., Ночка будет весела - не заснешь возле стола!, „Комсомольская правда" 29.12.2001.

К и б и р о в Т., ***, [в:] электронный pecypc: http://magazines.russ.ru/druzhba /1999/9/kibir-pr.html (15.06.2014).

М у с т а ф и н а 3., Подружки тебе не подружки, „Труд” 14.09.2006.

Новый словарь русского языка: толково-словообразовательный, ред. Т.Ф. Евремова, т. 1 и 2, Москва 2000 (сокращ. - ТСЕ).

Русский семантический словарь: толковый словарь, систематизированный по классам слов и значений, ред. Н.Ю. Шведова, т. 1, Москва 1998 (слокращ. - ТСШ).

С к о р о х о д Н.С. , Леонид Андреев, [в:] электронный ресурс: http://www.litmir. $\mathrm{me} / \mathrm{br} / \mathrm{?b}=214002 \& \mathrm{p}=6(11.10 .2014)$.

Электронный ресурс: http://www.kinopoisk.ru/film/46614/ (10.09.2012). 